Article

\title{
Ecological and Human Health Risks of Heavy Metals in Shooting Range Soils: A Meta Assessment from China
}

\author{
Juan Bai ${ }^{1}$ and Xiaofen Zhao ${ }^{2, *(D)}$ \\ 1 College of Physical Education, Qingdao University of Science and Technology, Qingdao 266061, China; \\ baijuan@qust.edu.cn \\ 2 Library, Qingdao University of Science and Technology, Qingdao 266061, China \\ * Correspondence: zhaoxiaofen@qust.edu.cn; Tel.: +86-532-8895-7796
}

Received: 29 March 2020; Accepted: 25 April 2020; Published: 1 May 2020

\begin{abstract}
Contamination of shooting ranges by heavy metals in particular $\mathrm{Pb}$ represents a widespread environmental issue attracting concern worldwide. Contaminant accumulation in shooting range soils can pose potential ecological risks and health risks for shooters and workers. Based on the published data on metal contamination at five shooting ranges in China, potential ecological and human health risks of several metals, and in particular, $\mathrm{Pb}$ were assessed for the five surveyed shooting ranges. Data show the mean concentrations of $\mathrm{Pb}, \mathrm{Cu}, \mathrm{Hg}, \mathrm{Sb}, \mathrm{Ni}$ and $\mathrm{Cr}$ in various ranges were all higher than the local soil background values, implying their accumulation was induced by shooting activities. The degree of contamination varied with sites and metals, very high $\mathrm{Pb}$ contamination at Range 1, Range 2 and Range 5-1, while moderate Pb contamination at Range 3 and Range 5-2. Comparatively, As, $\mathrm{Zn}$ and Co showed no contamination. Among the surveyed metals, $\mathrm{Pb}, \mathrm{Cu}, \mathrm{Hg}$ and $\mathrm{Sb}$ in shooting range soils displayed relatively high potential ecological risks. The overall degree of potential ecological risk was very high at Range 1 and Range 2, considerable at Range 4 and Range 5-1, and low at Range 3 and Range 5-2. The mean HI (hazard index) of Pb at Range 2 and the maximum $\mathrm{HI}$ values at Range 1 and Range 4 were higher than 1 , suggesting a possibility of non-carcinogenic risks of $\mathrm{Pb}$ contamination at these sites. However, $\mathrm{Pb}$ in other range soils and other metals, across the five ranges, all exhibited no non-carcinogenic risks. The cancer risks of the four carcinogenic contaminants ( $\mathrm{As}, \mathrm{Co}, \mathrm{Cr}$, and $\mathrm{Ni}$ ) were acceptable or negligible at all ranges. In conclusion, contamination of $\mathrm{Pb}$ and other metals such as $\mathrm{Cu}, \mathrm{Hg}$ and $\mathrm{Sb}$ can cause various potential ecological risks at all the surveyed ranges, but only $\mathrm{Pb}$ at three ranges shows possible health risks. Contamination of $\mathrm{Pb}$ in the surveyed shooting ranges should be managed to reduce its possible environmental and health risks.
\end{abstract}

Keywords: health risk; heavy metals; shooting range; ecological risk; soil pollution

\section{Introduction}

Toxic metals without known biological functions (e.g., $\mathrm{Pb}, \mathrm{Cd}$, and $\mathrm{As}$ ) and even some essential metals for human beings (e.g., $\mathrm{Cu}, \mathrm{Zn}$, and $\mathrm{Cr}$ ) can cause health risks when present in excess levels. It is well known that excessive intake of $\mathrm{Pb}$ can cause damages in human biological systems such as nervous system, immune system and reproductive system, and especially children's brain development [1]. Some toxic metals, such as $\mathrm{Pb}, \mathrm{As}, \mathrm{Cd}$ and $\mathrm{Cr}$ have been classified as carcinogenic elements by the International Agency for Research on Cancer [2]. Thus, contaminant status and potential risks of the sites, closely related to human health, require serious consideration.

Due to the composition of metals in bullets and shells, shooting activity has been recognized as an important soil pollution source of heavy metals, such as $\mathrm{Pb}[3,4]$. It is estimated that 10 to 60,000 tons of 
$\mathrm{Pb}$ is released annually in shooting ranges in different countries, ranked as the second largest source of $\mathrm{Pb}$ contamination after battery industry [5]. According to an estimate by U.S. Environmental Protection Agency (USEPA), about $7.26 \times 10^{4}$ ton of $\mathrm{Pb}$ shot and bullets are used annually at approximately 9000 nonmilitary shooting ranges [6]. The discharged shot and bullets, as well as the release of $\mathrm{Pb}$ powder, lead to $\mathrm{Pb}$ accumulation in shooting range soils [4]. Numerous investigations have confirmed that $\mathrm{Pb}$ can accumulate in soil at and around shooting ranges after years of shooting activity, and ultimately reach pollution levels. For instance, $\mathrm{Pb}$ concentrations of 10,000-70,000 mg/kg have been reported in shooting range soil [7]. At another shooting range in the US, Pb concentrations varied ranging from 27,000 to $233,142 \mathrm{mg} / \mathrm{kg}$ [8]. Furthermore, due to the complex components of bullets/shots used in shooting, contaminants such as $\mathrm{Cu}, \mathrm{Sb}, \mathrm{Zn}$ and $\mathrm{Ni}$ were also reported in shooting range soils [3]. A case study from small arms shooting ranges showed that the concentrations of $\mathrm{Pb}, \mathrm{Cu}, \mathrm{Zn}$ and $\mathrm{Sb}$ reached $13,5.2,1.1$, and $0.83 \mathrm{~g} / \mathrm{kg}$, respectively [9]. Undoubtedly, soil contamination with $\mathrm{Pb}$, as well as the co-contaminants may cause direct and indirect consequences for human health.

As summarized in two reviews $[3,4]$, previous studies were focused mainly on the contamination status, environmental fate and management of $\mathrm{Pb}$ and other co-contaminants in shooting range soils. Particularly, $\mathrm{Pb}$ in shooting range soils can be highly bioavailable, indicating a potential toxicity and environmental risk [3]. However, only few studies assessed their environmental and health risks [10-13]. Although several studies investigated heavy metal contamination status of shooting ranges in China, to our knowledge, no studies have been conducted on their ecological and health risks. In our present study, we assessed the potential ecological risks and health risks of the contaminants, based on the published data on heavy metal contamination in shooting ranges in China.

\section{Materials and Methods}

\subsection{Data Collecting}

We searched the published journal and conference papers based on several international databases, such as Google Scholar, Scopus, Web of Science, and the biggest database in China (China National Knowledge Infrastructure, CNKI). The following search items were included: Shooting range contamination/pollution, shooting range soil, lead/heavy metals, and/or China. Finally, five papers published in international and Chinese journals were collected (see Table 1). In total, five shooting ranges were studied, among which, the fifth was divided into two sampling areas for investigation. Thus, the ranges were numbered in chronological order as Range 1, Rang 2, Range 3, Range 4, Rang 5-1, and Range 5-2, respectively.

Thereafter, the data on heavy metal concentrations in tables and figures in the published papers were extracted directly, or using the software GetData Graph Digitizer version 2.26 (GETDATA Graph Digitizer, Moscow, Russia, 2013). The mean, maximum and minimum values were used for calculation of risk assessment.

\subsection{Assessment of Contamination Degree and Potential Ecological Risk}

The following equations were used to assess the contamination degree and potential ecological risk of heavy metals in shooting range soils [14]:

$$
\begin{gathered}
\mathrm{CF}=\frac{\mathrm{C}_{\text {metal }}}{\mathrm{C}_{\text {background }}} \\
\mathrm{CD}=\sum_{i=1}^{n} \mathrm{CF} \\
\text { Eri }=\operatorname{Tr} \times \mathrm{CF} \\
\mathrm{RI}=\sum_{i=1}^{n} \text { Eri. }
\end{gathered}
$$


Contamination factor (CF) can be calculated using the ratio of the specific metal concentration in soil to its soil background value (Equation (1)). The concentration of each individual metal $\left(\mathrm{C}_{\text {metal }}\right)$ was from the published data (Table 1$)$. The background values $\left(C_{\text {background }}\right)$ of these metals were shown in Table S1 [15]. The degree of contamination (CD) is the summation of the CF of each metal (Equation (2)). The toxic response factor ( $\operatorname{Tr}$ ) for the given metal was cited from previous references $[14,16,17]$ (Table S1). The ecological risk factor (Eri) is defined as the product of CF and $\operatorname{Tr}$ (Equation (3)), and ecological risk index (RI) is defined as the sum of Eri of all metals in soil (Equation (4)). The classification of degree of contamination and ecological risk is shown in Table S2 [14].

\subsection{Health Risk Assessment}

Health risks of contaminants were evaluated based on USEPA's Exposure Factors Handbook and Exposure Factors Handbook of Chinese Population (Adults) [18]. Average daily doses (ADDs) of contaminants via ingestion, inhalation and dermal contact were calculated based on the following Equations (Equations (5)-(7)). The parameters in the Equations (5)-(7) were presented in Table S3:

$$
\begin{gathered}
\mathrm{ADD}_{\text {ing }}=\mathrm{C}_{\text {metal }} \times \frac{\mathrm{IngR} \times \mathrm{TEF} \times \mathrm{ED}}{\mathrm{BW} \times \mathrm{AT}} \times 10^{-6} \\
\mathrm{ADD}_{\text {inh }}=\mathrm{C}_{\text {metal }} \times \frac{\mathrm{InhR} \times \mathrm{TEF} \times \mathrm{ED}}{\mathrm{PEF} \times \mathrm{BW} \times \mathrm{AT}} \\
\mathrm{ADD}_{\text {der }}=\mathrm{C}_{\text {metal }} \times \frac{\mathrm{SL} \times \mathrm{SA} \times \mathrm{ABS} \times \mathrm{TEF} \times \mathrm{ED}}{\mathrm{BW} \times \mathrm{AT}} \times 10^{-6}
\end{gathered}
$$

The potential non-carcinogenic and carcinogenic risks were calculated using hazard quotient $(\mathrm{HQ})$, and cancer risk (CR), respectively (Equations (8) and (9)). Hazard index (HI) is the summation of the HQs for the three exposure routes (Equation (10)). The value of HQ or HI $>1$ means a possibility of non-carcinogenic risk, and the value of $\mathrm{HQ}$ or $\mathrm{HI}<1$ means no significant non-carcinogenic risk. The total carcinogenic risk (TR) is the summation of the CRs for the three exposure routes (Equation (11)). The cancer risk is negligible when CR or TR lower than $1 \times 10^{-6}$, and acceptable or tolerable for the range of $1 \times 10^{-6}$ to $1 \times 10^{-4}$. The value of CR or TR higher than $1 \times 10^{-4}$ means that 1 in 10,000 persons may develop cancer from lifetime exposure to carcinogenic risks. The definitions and values of RfD and SF were presented in Table S4 [16,19-21]:

$$
\begin{gathered}
\mathrm{HQ}=\frac{\mathrm{ADD}}{\mathrm{RfD}} \\
\mathrm{HI}=\sum \mathrm{HQ} \\
\mathrm{CR}=\mathrm{ADD} \times \mathrm{SF} \\
\mathrm{TR}=\sum \mathrm{CR} .
\end{gathered}
$$


Table 1. Concentrations of various metals in shooting rang soils reported in China.

\begin{tabular}{|c|c|c|c|c|c|c|c|c|c|c|c|c|}
\hline Number of Ranges & Shooting Range & Value (mg/kg) & $\mathbf{P b}$ & $\mathrm{Cu}$ & $\mathrm{Hg}$ & As & $\mathrm{Sb}$ & $\mathrm{Zn}$ & $\mathrm{Ni}$ & $\mathrm{Cr}$ & Co & References \\
\hline \multirow{3}{*}{ Range 1} & \multirow{3}{*}{$\begin{array}{l}\text { Small arms shooting range: bullet berms and } \\
\text { target zones }(0-5 \mathrm{~cm}) ; \mathrm{pH} 7.70-8.65\end{array}$} & Mean & 936.4 & 88.4 & 36.9 & 9.54 & 1.97 & 40.2 & & & & \multirow{3}{*}{ [22] } \\
\hline & & Max & 7031 & 448 & 149 & 13.4 & 14.0 & 91.5 & & & & \\
\hline & & Min & 12.5 & 11.6 & 13.7 & 4.67 & 0.17 & 20.3 & & & & \\
\hline \multirow{3}{*}{ Range 2} & \multirow{3}{*}{$\begin{array}{l}\text { Small arms shooting range }(15 \text { years): bullet } \\
\text { berms and target zones }(0-5 \mathrm{~cm}) ; \mathrm{pH} 8.2-9.0\end{array}$} & Mean & 4175 & & & & & & & & & \multirow{3}{*}{ [23] } \\
\hline & & Max & 7674 & & & & & & & & & \\
\hline & & Min & 132 & & & & & & & & & \\
\hline \multirow{3}{*}{ Range 3} & \multirow{3}{*}{$\begin{array}{l}\text { Tank shooting range }(20 \text { years): shot fall and } \\
\text { non-shot fall zones }(0-15 \mathrm{~cm}) \text {; mean pH } 5.96 \text {; }\end{array}$} & Mean & 30.33 & 46.29 & & & & 56.71 & 32.73 & & 9.82 & \multirow{3}{*}{ [24] } \\
\hline & & Max & 52.49 & 101.90 & & & & 91.27 & 56.50 & & 19.77 & \\
\hline & & Min & 20.52 & 27.25 & & & & 32.17 & 19.05 & & 5.03 & \\
\hline \multirow{3}{*}{ Range 4} & \multirow{3}{*}{$\begin{array}{l}\text { Small arms shooting range (15 years): shooting } \\
\text { and target zones }(0-20 \mathrm{~cm}) \text {; mean pH } 7.31\end{array}$} & Mean & 2044.5 & 183.4 & & & & 68.1 & 34.2 & 88.9 & & \multirow{3}{*}{ [25] } \\
\hline & & Max & 5010.0 & 396.5 & & & & 91.1 & 38.8 & 98.2 & & \\
\hline & & Min & 151.9 & 44.1 & & & & 47.9 & 28.1 & 80.6 & & \\
\hline \multirow{3}{*}{ Range 5-1 } & \multirow{3}{*}{$\begin{array}{l}\text { Small arms shooting range (20 years): } \\
\text { Bomb-beaten area }(0-20 \mathrm{~cm}) ; \text { mean } \mathrm{pH} 6.64\end{array}$} & Mean & 1375.35 & 214.62 & & & & & & & & \multirow{6}{*}{ [26] } \\
\hline & & Max & 2763 & 306.90 & & & & & & & & \\
\hline & & Min & 414 & 104 & & & & & & & & \\
\hline \multirow{3}{*}{ Range 5-2 } & Small arms shooting range (20 years): & Mean & 55.21 & 41.95 & & & & & & & & \\
\hline & Non-bomb dropping area $(0-20 \mathrm{~cm})$; mean $\mathrm{pH}$ & Max & 153.70 & 226.20 & & & & & & & & \\
\hline & 6.64 & Min & 22.58 & 17.04 & & & & & & & & \\
\hline \multirow{2}{*}{ China's soil environmental quality } & Risk screening value & & 800 & 18,000 & 38 & 60 & & & 900 & & & [27] \\
\hline & Risk intervention value & & 2500 & 36,000 & 82 & 140 & & & 2000 & & & [27] \\
\hline
\end{tabular}

Note: Blank space means data were not provided. In references [22,23], the metals were determined using an inductively coupled plasma optical emission spectrometer and hydride generation-atomic fluorescence spectrophotometer after microwave digestion. In references [23-25], the metals were determined using an inductively coupled plasma optical emission spectrometer after digestion based on USEPA Method 3050B. 


\subsection{Data Analysis}

The mean, maximum and minimum concentrations of each metal were used for calculating the above parameters using Excel 2016 (Microsoft Corporation, Redmond, WA, USA).

\section{Results and Discussion}

\subsection{Heavy Metal Concentrations in Shooting Range Soils of China}

A total of five shooting ranges were listed in chronological order (Table 1). These shooting ranges (except Range 1) were known to have been open for more than 15 years. Among them, only Range 3 was tank shooting range, while others were all involved in small arms, such as pistols, rifles, and submachine guns.

Generally, high $\mathrm{Pb}$ concentrations were detected in soils of small arms shooting ranges (Range 1, Range 2, Range 4, and Range 5-1), with the highest value of $7674 \mathrm{mg} / \mathrm{kg}$ at Range 2. However, large variations were observed, and the maximum concentrations were one to two orders of magnitude higher than the minimum values. Comparatively, in the tank shooting range (Range 3), $\mathrm{Pb}$ concentrations were much lower. Even in the same range, $\mathrm{Pb}$ concentrations were much lower in non-bomb dropping area than in bomb-beaten area. In addition to $\mathrm{Pb}$, some other metals including $\mathrm{Cu}$, $\mathrm{Hg}, \mathrm{As}, \mathrm{Sb}, \mathrm{Zn}, \mathrm{Ni}, \mathrm{Cr}$ and $\mathrm{Co}$ were also detected in some ranges.

Obviously, the accumulation of metals resulted mainly from gunshot residues released by shooting activities, such as fragments of the bullet, cartridge case, burnt and unburnt particles from gunpowder. Ammunitions of light and heavy weapons often contained heavy metals. The most common bullets consist of a $\mathrm{Pb}$ core and a $\mathrm{Cu}$ outer jacket. It is estimated that most bullets contain over $90 \% \mathrm{~Pb}, 1$ to $5 \% \mathrm{Sb}$, and up to $9 \% \mathrm{Cu}$ for jacketed bullets, and some other minor alloying agents such as $\mathrm{Zn}$, As, and $\mathrm{Ni}$ [6]. In Pb-bullets, 95-97\% of the weight is metallic $\mathrm{Pb}$, following by $0.4-2.0 \% \mathrm{Sb}, 0.2-0.8 \%$ As, and other metals such as $\mathrm{Sn}, \mathrm{Se}, \mathrm{Mn}, \mathrm{Cd}, \mathrm{Cr}, \mathrm{Cu}$, and $\mathrm{Ni}$ [28]. $\mathrm{Hg}$ compounds were used in primers for rifle and handgun ammunition [29]. In tank shells, the common components are steel alloy, brass, $\mathrm{Cu} / \mathrm{Zn}$ alloy, Ni alloy and aluminum alloy [24]. After the shooting activities, the abrasion and weathering of fired bullets or shots lead to metal release and accumulation in shooting range soils.

According to the "Soil Environmental Quality-Risk control standard for soil contamination of agricultural land (GB 15618-2018)", most Pb concentrations in small arms shooting ranges exceed this risk screening value, indicating risk assessment should be performed for these sites. Maximum values of $\mathrm{Pb}$ in some sites and maximum $\mathrm{Hg}$ value in Range 1 exceed their risk intervention values, indicating risk control and remediation measures should be taken for these sites.

\subsection{Assessment of Contamination Degree}

As shown in Table 2, the mean $\mathrm{CF}$ values of $\mathrm{Pb}, \mathrm{Cu}, \mathrm{Hg}, \mathrm{Sb}, \mathrm{Ni}$ and $\mathrm{Cr}$ were all higher than 1 , while the values of $\mathrm{As}, \mathrm{Zn}$ and $\mathrm{Co}$ were lower than $1 . \mathrm{Pb}$ contamination degree varied with sites, with very high contamination in Range 1, Range 2 and Range 5-1, while moderate contamination in Range 3 and Range 5-2. Cu contamination degree reached very high in Range 4 and Range 5-1, considerable in Range 1, and moderate in Range 3 and Range 5-2. The mean CF value of $\mathrm{Hg}$ in Range 1 was as high as 567.7, representing a very high degree of contamination. The mean CF values of $\mathrm{Sb}, \mathrm{Ni}$ and $\mathrm{Cr}$ all ranged from 1 to 3, indicating moderate contamination at these sites. As, $\mathrm{Zn}$ and Co levels at the surveyed sites were classified as low contamination. The CD values confirmed that very high contamination occurred in Range 1, Range 2, Range 4, and Range 5-1. However, the low contamination degree in Range 3 may not reflect the real situation, because not all metals were fully investigated at this site, particularly the metals with low background values (e.g., $\mathrm{Hg}$ and $\mathrm{Sb}$ ). 
Table 2. Contamination factor (CF), contamination degree (CD), ecological risk factor (Eri), and potential ecological risk index (RI) of heavy metals in the shooting ranges.

\begin{tabular}{|c|c|c|c|c|c|c|c|c|c|c|c|c|c|c|c|c|c|c|c|}
\hline \multirow{2}{*}{ Metal } & \multirow{2}{*}{ Value } & \multicolumn{3}{|c|}{ Range 1} & \multicolumn{3}{|c|}{ Range 2} & \multicolumn{3}{|c|}{ Range 3} & \multicolumn{3}{|c|}{ Range 4} & \multicolumn{3}{|c|}{ Range 5-1 } & \multicolumn{3}{|c|}{ Range 5-2 } \\
\hline & & Mean & Max & Min & Mean & Max & Min & Mean & Max & Min & Mean & Max & Min & Mean & Max & Min & Mean & Max & Min \\
\hline \multirow[t]{2}{*}{$\mathrm{Pb}$} & $\mathrm{CF}$ & 36.0 & 270.4 & 0.5 & 160.6 & 295.2 & 5.1 & 1.2 & 2.0 & 0.8 & 78.6 & 192.7 & 5.8 & 52.9 & 106.3 & 15.9 & 2.1 & 5.9 & 0.9 \\
\hline & Eri & 180.1 & 1352 & 2.4 & 802.9 & 1476 & 25.4 & 5.8 & 10.1 & 3.9 & 393.2 & 963.5 & 29.2 & 264.5 & 531.3 & 79.6 & 10.6 & 29.6 & 4.3 \\
\hline \multirow[t]{2}{*}{$\mathrm{Cu}$} & CF & 3.9 & 19.8 & 0.5 & & & & 2.0 & 4.5 & 1.2 & 8.1 & 17.5 & 2.0 & 9.5 & 13.6 & 4.6 & 1.9 & 10.0 & 0.8 \\
\hline & Eri & 19.6 & 99.1 & 2.6 & & & & 10.2 & 22.5 & 6.0 & 40.6 & 87.7 & 9.8 & 47.5 & 67.9 & 23.0 & 9.3 & 50.0 & 3.8 \\
\hline \multirow[t]{2}{*}{$\mathrm{Hg}$} & $\mathrm{CF}$ & 567.7 & 2292 & 210.8 & & & & & & & & & & & & & & & \\
\hline & Eri & 22,700 & 91,690 & 8430 & & & & & & & & & & & & & & & \\
\hline \multirow[t]{2}{*}{ As } & CF & 0.9 & 1.2 & 0.4 & & & & & & & & & & & & & & & \\
\hline & Eri & 8.5 & 12.0 & 4.2 & & & & & & & & & & & & & & & \\
\hline \multirow[t]{2}{*}{$\mathrm{Sb}$} & $\mathrm{CF}$ & 1.6 & 11.6 & 0.1 & & & & & & & & & & & & & & & \\
\hline & Eri & 16.3 & 115.7 & 1.4 & & & & & & & & & & & & & & & \\
\hline \multirow[t]{2}{*}{$\mathrm{Zn}$} & CF & 0.5 & 1.2 & 0.3 & & & & 0.8 & 1.2 & 0.4 & 0.9 & 1.2 & 0.6 & & & & & & \\
\hline & Eri & 0.5 & 1.2 & 0.3 & & & & 0.8 & 1.2 & 0.4 & 0.9 & 1.2 & 0.6 & & & & & & \\
\hline \multirow[t]{2}{*}{$\mathrm{Ni}$} & $\mathrm{CF}$ & & & & & & & 1.2 & 2.1 & 0.7 & 1.3 & 1.4 & 1.0 & & & & & & \\
\hline & Eri & & & & & & & 6.1 & 10.5 & 3.5 & 6.4 & 7.2 & 5.2 & & & & & & \\
\hline \multirow[t]{2}{*}{$\mathrm{Cr}$} & CF & & & & & & & & & & 1.5 & 1.6 & 1.3 & & & & & & \\
\hline & Eri & & & & & & & & & & 2.9 & 3.2 & 2.6 & & & & & & \\
\hline \multirow[t]{4}{*}{ Co } & $\mathrm{CF}$ & & & & & & & 0.8 & 1.6 & 0.4 & & & & & & & & & \\
\hline & Eri & & & & & & & 3.9 & 7.8 & 2.0 & & & & & & & & & \\
\hline & $C D$ & 610.6 & 2597 & 212.6 & 160.6 & 295.2 & 5.1 & 6.0 & 11.4 & 3.5 & 90.4 & 214.5 & 10.8 & 62.4 & 119.8 & 20.5 & 4.0 & 15.9 & 1.6 \\
\hline & IR & 22,930 & 93,270 & 8442 & 802.9 & 1476 & 25.4 & 26.8 & 52.2 & 15.9 & 443.9 & 1063 & 47.5 & 312.0 & 599.2 & 102.6 & 19.9 & 79.6 & 8.1 \\
\hline
\end{tabular}


The present data confirm heavy metal contamination particularly $\mathrm{Pb}$ contamination at all the surveyed shooting ranges, but the contamination degree varies greatly with sampling location and shooting range type. Due to the variability of shooting activities, metal pollution is unlikely to occur evenly in the range. $\mathrm{Pb}$ contamination generally shows heterogeneity at shooting ranges, with the highest density of $\mathrm{Pb}$ bullets usually in the berm [4]. For pistol and rifle ranges, high concentrations of contaminants, $\mathrm{Pb}$ in particular, generally accumulate in bullet berms and shot fall zones [3]. The highest total $\mathrm{Pb}$ concentration of $38406 \mathrm{mg} / \mathrm{kg}$ was detected in the berm soils of Thebephatshwa shooting range [30]. For target ranges, a maximum value of $26,700 \mathrm{mg} / \mathrm{kg} \mathrm{Pb}$ was observed near the center of the expected shot fallout zone [31]. Thus, it is probable that bomb-beaten zone had higher $\mathrm{Pb}$ concentrations than non-bomb dropping area at Range 3.

On the other hand, metal species and concentrations in shooting range soil depend on the components of bullets or shells, while metallic components of bullets or shots vary by purpose and by manufacturer [6]. Most common bullets contain over $90 \% \mathrm{~Pb}$, as well as other minor components such as $\mathrm{Cu}, \mathrm{Ab}, \mathrm{As}, \mathrm{Cr}, \mathrm{Ni}[6,28]$. In contrast, in tank shells, the common components are steel alloy, brass, copper-zinc alloy, and other alloys [24], which can explain the reason high levels of Pb generally accumulated in the small arms shooting ranges, but not in the tank shooting range. Meanwhile, the components of minor metals in bullets and shells can also explain their accumulation in soil. Thus, it can be concluded that, heavy metal concentrations and contamination degrees in shooting ranges are site-specific, varying greatly with the type and sampling location.

\subsection{Assessment of Potential Ecological Risk}

Based on Eri values shown in Table 2, potential ecological risk of $\mathrm{Pb}$ could be classified as very high for Range 2 and Range 4, high for Range 1 and Range 5-1, and low for Range 3 and Range 5-2. The mean Eri values of $\mathrm{Cu}$ at Range 4 and Range 5-1, and the maximum Eri values of $\mathrm{Cu}$ at Range 1 and Range 5-2 were all higher than 40, but lower than 160, indicating moderate or considerable potential ecological risks of $\mathrm{Cu}$ at these sites. For Range 1, even the minimum Eri value of $\mathrm{Hg}$ reached as high as 8430.8 , meaning its very high potential ecological risk. Although the mean Eri values of Sb at Range 1 did not exceed 40, but the maximum value reached as high as 115.7, which means at least some sampling points of Range 1 have considerable potential ecological risk. For other metals $\mathrm{Zn}, \mathrm{Cr}$, $\mathrm{Ni}$ and $\mathrm{Co}$, all their Eri values were lower than 40, suggesting their low risks at these sites. Considering the values of IR, the overall degree of potential ecological risk was very high at Range 1 and Range 2, considerable at Range 4 and Range 5-1, and low at Range 3 and Range 5-2.

The present data confirm potential ecological risks of $\mathrm{Pb}, \mathrm{Cu}, \mathrm{Hg}$ and $\mathrm{Sb}$ in shooting range soils. Generally, $\mathrm{Pb}$ is considered the most widespread risky contaminant in most shooting ranges. At two military shooting ranges in Korea, Eri value of $\mathrm{Pb}$ reached 3446, and 725, respectively [12]. In seven shooting ranges in Botswana, the Eri value of $\mathrm{Pb}$ ranged from 1192 to 56,272 [13]. Peddicord and LaKind [11] first evaluated the ecological risks of shooting rang contaminants for some animals, and found that $\mathrm{Pb}$ posed substantial risks to small mammals and grit-ingesting birds, but other contaminants, including $\mathrm{As}, \mathrm{Sb}, \mathrm{Cu}, \mathrm{Zn}$ and $\mathrm{PAHs}$ posed minimal risks. One rifle and shotgun shooting site in Finland was shown to have high ecological risks to terrestrial and aquatic organisms, and $\mathrm{Pb}$ was the most important contaminant. However, the data from Range 1 showed that $\mathrm{Hg}$ had much higher ecological risks than $\mathrm{Pb}$ on Range 1. Since $\mathrm{Hg}$ can persist in shooting rang soil for a long term [29], $\mathrm{Hg}$ contamination and environmental risks deserves more attention in future study. Furthermore, considering their potential ecological risks, contamination of $\mathrm{Cu}$ and $\mathrm{Sb}$ at shooting ranges are also not negligible.

More interestingly, contaminants in shooting range soils have been confirmed to accumulate in organisms inhabiting there. $\mathrm{Pb}$ concentration in Stipa krylovii plants grown in the soil at Range 1 was 16 times of that in the control plants [22]. In another study, $\mathrm{Pb}$ at rifle and pistol ranges could be accumulated by earthworms and vegetation, and imposed elevated risk for their consumers through the food chain [32]. Bioaccumulation or biomagnification of $\mathrm{Pb}$ and $\mathrm{Cu}$ in plants and invertebrates 
was observed at shooting sites [33]. Moreover, $\mathrm{Pb}$ contamination of an old shooting range, not only negatively affected soil microbes and enchytraeid worms, but also disturbed ecological processes, such as decomposition and nutrient mineralization [34]. Undoubtedly, the ecological risks of shooting ranges at the ecosystem scale need to be assessed.

\subsection{Health Risk Assessment}

The values of $\mathrm{HI}$ and TR via the three exposure routes were shown in Table 3. The mean HI value of $\mathrm{Pb}$ at Range 2, and the maximum $\mathrm{HI}$ values of $\mathrm{Pb}$ at Range 1 and Range 4, were higher than 1 , suggesting a possibility of non-carcinogenic effects of $\mathrm{Pb}$ contamination at these sites. However, $\mathrm{Pb}$ in other range soils and other metals across the five ranges all showed no non-carcinogenic risks.

The cancer risks of the four carcinogenic contaminants (As, Co, Cr, and Ni) were measured (Table 4). Generally, TR values of As at Range 1 were higher than $1 \times 10^{-6}$, but lower than $1 \times 10^{-5}$, suggesting that the possible carcinogenic risks from exposure of As were acceptable. However, TR values of $\mathrm{Cr}$, $\mathrm{Co}$ and $\mathrm{Ni}$, and their sums were all much lower than $1 \times 10^{-6}$, indicating the potential cancer risks can be considered negligible at Range 3 and Range 4 .

Heavy metal accumulation in shooting range soil can pose health risks via exposure routes such as ingestion, respiratory inhalation, and dermal contact, particularly for workers and shooters of shooting ranges [4]. Here, our results indicated that, among the surveyed metals, $\mathrm{Pb}$ had the highest possibility of non-carcinogenic risks, and ingestion exposure route accounted for the highest contribution, followed by dermal contact and then inhalation (data not shown). Soil particles or dust-bearing Pb can be released during shooting activities by shooters and maintenance operations by workers, and then produce health risks via exposure routes, such as hand-mouth intake. In particular, Pb dust is not only in direct contact with the workers' skins, but also adheres to their clothing and shoes, thereby potentially exposing their families to $\mathrm{Pb}$ if the dust is taken home.

Although $\mathrm{Hg}$ sometimes showed a very high contamination degree and potential ecological risks, its non-carcinogenic risks were negligible. The high ecological risks of $\mathrm{Hg}$ are mainly from its high toxicity factor, but its absolute contents are quite low compared to $\mathrm{Pb}$, and thereby human exposure risks are also relatively low. Thus, the contamination degree and ecological risk of $\mathrm{Hg}$, based on the methods in our study, may be overestimated. Other metals, irrespective of their contamination degree and potential ecological risks, all did not show significant carcinogenic and non-carcinogenic risks.

Notably, compared to other contaminants, $\mathrm{Pb}$ in shooting ranges is sometimes of high mobility and availability, and may cause contamination of surface and groundwater, thereby imposing risks to the general public [3,4]. Via surface runoff and atmospheric precipitation, contaminants in polluted shooting ranges can spread to surrounding environments and induce adverse impacts on the organisms therein. Therefore, for shooting ranges with potential ecological and health risks, it is necessary to adopt management practices for risk control and environmental remediation. 
Table 3. Non-carcinogenic risks (HI) of heavy metals in shooting range soils.

\begin{tabular}{|c|c|c|c|c|c|c|c|c|c|c|c|c|c|c|c|c|c|c|}
\hline \multirow{2}{*}{ Metal } & \multicolumn{3}{|c|}{ Range 1} & \multicolumn{3}{|c|}{ Range 2} & \multicolumn{3}{|c|}{ Range 3} & \multicolumn{3}{|c|}{ Range 4} & \multicolumn{3}{|c|}{ Range 5-1 } & \multicolumn{3}{|c|}{ Range 5-2 } \\
\hline & Mean & $\operatorname{Max}$ & Min & Mean & $\operatorname{Max}$ & Min & Mean & Max & Min & Mean & Max & Min & Mean & Max & Min & Mean & Max & Min \\
\hline $\mathrm{Pb}$ & $3.26 \times 10^{-1}$ & 2.45 & $4.35 \times 10^{-3}$ & 1.45 & 2.67 & $4.60 \times 10^{-2}$ & $1.06 \times 10^{-2}$ & $1.83 \times 10^{-2}$ & $7.14 \times 10^{-3}$ & $7.12 \times 10^{-1}$ & 1.74 & $5.29 \times 10^{-2}$ & $4.79 \times 10^{-1}$ & $9.62 \times 10^{-1}$ & $1.44 \times 10^{-1}$ & $1.92 \times 10^{-2}$ & $5.35 \times 10^{-2}$ & $7.86 \times 10^{-3}$ \\
\hline $\mathrm{Cu}$ & $2.66 \times 10^{-3}$ & $1.35 \times 10^{-2}$ & $3.49 \times 10^{-4}$ & & & & $1.39 \times 10^{-3}$ & $3.06 \times 10^{-3}$ & $8.19 \times 10^{-4}$ & $5.51 \times 10^{-3}$ & $1.19 \times 10^{-2}$ & $1.33 \times 10^{-3}$ & $6.45 \times 10^{-3}$ & $9.23 \times 10^{-3}$ & $3.13 \times 10^{-3}$ & $1.26 \times 10^{-3}$ & $6.80 \times 10^{-3}$ & $5.12 \times 10^{-4}$ \\
\hline $\mathrm{Hg}$ & $1.54 \times 10^{-1}$ & $6.23 \times 10^{-1}$ & $5.73 \times 10^{-2}$ & & & & & & & & & & & & & & & \\
\hline As & $3.81 \times 10^{-2}$ & $5.35 \times 10^{-2}$ & $1.87 \times 10^{-2}$ & & & & & & & & & & & & & & & \\
\hline $\mathrm{Sb}$ & $6.00 \times 10^{-3}$ & $4.26 \times 10^{-2}$ & $5.18 \times 10^{-4}$ & & & & & & & & & & & & & & & \\
\hline $\mathrm{Zn}$ & $1.62 \times 10^{-4}$ & $3.69 \times 10^{-4}$ & $8.19 \times 10^{-5}$ & & & & $2.29 \times 10^{-4}$ & $3.68 \times 10^{-4}$ & $1.30 \times 10^{-4}$ & $2.75 \times 10^{-4}$ & $3.68 \times 10^{-4}$ & $1.93 \times 10^{-4}$ & & & & & & \\
\hline $\mathrm{Ni}$ & & & & & & & $1.97 \times 10^{-3}$ & $3.40 \times 10^{-3}$ & $1.15 \times 10^{-3}$ & $2.06 \times$ & $2.34 \times 10^{-3}$ & $1.69 \times 1$ & & & & & & \\
\hline $\mathrm{Cr}$ & & & & & & & & & & $4.26 \times 10^{-2}$ & $4.71 \times 10^{-2}$ & $3.86 \times 10^{-2}$ & & & & & & \\
\hline Co & & & & & & & $8.21 \times 10^{-4}$ & $1.65 \times 10^{-3}$ & $4.21 \times 10^{-4}$ & & & & & & & & & \\
\hline Sum & $5.27 \times 10^{-1}$ & 3.18 & $8.13 \times 10^{-2}$ & 1.45 & 2.67 & $4.60 \times 10^{-2}$ & $1.50 \times 10^{-2}$ & $2.68 \times 10^{-2}$ & $9.66 \times 10^{-3}$ & $7.62 \times 10^{-1}$ & 1.81 & $9.47 \times 10^{-2}$ & $4.85 \times 10^{-1}$ & $9.71 \times 10^{-1}$ & $1.47 \times 10^{-1}$ & $2.05 \times 10^{-2}$ & $6.03 \times 10^{-2}$ & $8.37 \times 10^{-3}$ \\
\hline
\end{tabular}


Table 4. Carcinogenic risks (TR) of heavy metals in shooting range soils.

\begin{tabular}{|c|c|c|c|c|c|c|c|c|c|}
\hline \multirow{2}{*}{ Metal } & \multicolumn{3}{|c|}{ Range 1} & \multicolumn{3}{|c|}{ Range 3} & \multicolumn{3}{|c|}{ Range 4} \\
\hline & Mean & Max & Min & Mean & Max & Min & Mean & Max & Min \\
\hline As & $5.89 \times 10^{-6}$ & $8.27 \times 10^{-6}$ & $2.88 \times 10^{-6}$ & & & & & & \\
\hline $\mathrm{Ni}$ & & & & $1.29 \times 10^{-9}$ & $2.23 \times 10^{-9}$ & $7.52 \times 10^{-10}$ & $1.35 \times 10^{-9}$ & $1.53 \times 10^{-9}$ & $1.11 \times 10^{-9}$ \\
\hline $\mathrm{Cr}$ & & & & & & & $1.75 \times 10^{-7}$ & $1.94 \times 10^{-7}$ & $1.59 \times 10^{-7}$ \\
\hline $\mathrm{Co}$ & & & & $4.52 \times 10^{-9}$ & $9.10 \times 10^{-9}$ & $2.32 \times 10^{-9}$ & & & \\
\hline Sum & $5.89 \times 10^{-6}$ & $8.27 \times 10^{-6}$ & $2.88 \times 10^{-6}$ & $5.81 \times 10^{-9}$ & $1.13 \times 10^{-8}$ & $3.07 \times 10^{-9}$ & $1.77 \times 10^{-7}$ & $1.95 \times 10^{-7}$ & $1.60 \times 10^{-7}$ \\
\hline
\end{tabular}

\section{Conclusions}

Our present results confirm that soil contamination by heavy metals in particular $\mathrm{Pb}$ commonly occurred in China's shooting ranges. Among the surveyed metals, $\mathrm{Pb}, \mathrm{Cu}, \mathrm{Hg}$ and $\mathrm{Sb}$ in shooting range soils displayed relatively high potential ecological risks. Due to its high concentration, non-carcinogenic risks of $\mathrm{Pb}$ contamination were observed at three of the surveyed sites. However, other metals across the five ranges did not display non-carcinogenic risks. The carcinogenic risks of the four carcinogenic metals (As, $\mathrm{Co}, \mathrm{Cr}$, and $\mathrm{Ni}$ ) were acceptable or negligible at all ranges. In conclusion, contamination of $\mathrm{Pb}$ and co-contaminants $\mathrm{Cu}, \mathrm{Hg}$ and $\mathrm{Sb}$ may produce potential ecological risks, but only $\mathrm{Pb}$ displays potential health risks. It is necessary to take measures to reduce the environmental and health risks of $\mathrm{Pb}$ contamination in shooting range soils.

Supplementary Materials: The following are available online at http://www.mdpi.com/2305-6304/8/2/32/s1, Table S1: Background values and toxic response factors of the surveyed metals, Table S2: The degree of contamination and potential ecological risk (Hakanson 1980) [14], Table S3: Parameters and their definitions and values in Equations (5)-(7), Table S4: Health risk assessment parameters for various metals.

Author Contributions: Data curation, X.Z.; funding acquisition, X.Z.; investigation, J.B.; methodology, J.B.; writing—original draft, X.Z.; writing—review and editing, J.B. All authors have read and agreed to the published version of the manuscript.

Funding: This work was supported by Qingdao Philosophy and Social Sciences Planning Project (QDSKL1901223), Social Science Popularization and Application Research Project of Shandong Province (2019-SKZZ-49), Humanities and Social Sciences Research Project of Qingdao University of Science and Technology (18XB25, 19XB08), and the Doctoral Foundation of QUST (0100229003).

Conflicts of Interest: The authors declare no conflict of interest.

\section{References}

1. Papanikolaou, N.C.; Hatzidaki, E.G.; Belivanis, S.; Tzanakakis, G.N.; Tsatsakis, A.M. Lead toxicity update. A brief review. Med. Sci. Monit. 2005, 11, RA329-RA336. [PubMed]

2. Tchounwou, P.B.; Yedjou, C.G.; Patlolla, A.K.; Sutton, D.J. Heavy metal toxicity and the environment. In Molecular, Clinical and Environmental Toxicology; Luch, A., Ed.; Springer: Berlin/Heidelberg, Germany, 2012; pp. 133-164.

3. Sanderson, P.; Qi, F.; Seshadri, B.; Wijayawardena, A.; Naidu, R. Contamination, fate and management of metals in shooting range soils-A review. Curr. Pollut. Rep. 2018, 4, 175-187. [CrossRef]

4. Fayiga, A.; Saha, U. Soil pollution at outdoor shooting ranges: Health effects, bioavailability and best management practices. Environ. Pollut. 2016, 216, 135-145. [CrossRef] [PubMed]

5. Ahmad, M.; Hashimoto, Y.; Moon, D.H.; Lee, S.S.; Ok, Y.S. Immobilization of lead in a Korean military shooting range soil using eggshell waste: An integrated mechanistic approach. J. Hazard. Mater. 2012, 209, 392-401. [CrossRef]

6. Lewis, J.; Sjöström, J.; Skyllberg, U.; Hägglund, L. Distribution, chemical speciation, and mobility of lead and antimony originating from small arms ammunition in a coarse-grained unsaturated surface sand. J. Environ. Qual. 2010, 39, 863-870. [CrossRef]

7. Fayiga, A.O.; Saha, $\mathrm{U}$. The effect of bullet removal and vegetation on mobility of $\mathrm{Pb}$ in shooting range soils. Chemosphere 2016, 160, 252-257. [CrossRef]

8. Interstate Technology and Regulatory Council. Characterization and Remediation of Soils at Closed Small Arms Firing Ranges; Interstate Technology and Regulatory Council, Small Arms Firing Range Team: Washington, DC, USA, 2003; pp. 1-2. 
9. Mariussen, E.; Johnsen, I.V.; Strømseng, A.E. Distribution and mobility of lead (Pb), copper $(\mathrm{Cu})$, zinc $(\mathrm{Zn})$, and antimony $(\mathrm{Sb})$ from ammunition residues on shooting ranges for small arms located on mires. Environ. Sci. Pollut. Res. 2017, 24, 10182-10196. [CrossRef]

10. Sorvari, J. Environmental risks at Finnish shooting ranges-A case study. Hum. Ecol. Risk Assess. 2007, 13, 1111-1146. [CrossRef]

11. Peddicord, R.K.; LaKind, J.S. Ecological and human health risks at an outdoor firing range. Environ. Toxicol. Chem. 2000, 19, 2602-2613. [CrossRef]

12. Islam, M.N.; Nguyen, X.P.; Jung, H.Y.; Park, J.H. Chemical speciation and quantitative evaluation of heavy metal pollution hazards in two army shooting range backstop soils. Bull. Environ. Contam. Toxicol. 2016, 96, 179-185. [CrossRef]

13. Dinake, P.; Kelebemang, R.; Sehube, N.; Kamwi, O.; Laetsang, M. Quantitative assessment of environmental risk from lead pollution of shooting range soils. Chem. Speciat. Bioavailab. 2018, 30, 76-85. [CrossRef]

14. Hakanson, L. An ecological risk index for aquatic pollution control. A sedimentological approach. Water Res. 1980, 14, 975-1001. [CrossRef]

15. China National Environmental Monitoring Centre. Soil Element Background Values in China; China Environmental Science Press: Beijing, China, 1990.

16. ur Rehman, I.; Ishaq, M.; Ali, L.; Khan, S.; Ahmad, I.; Din, I.U.; Ullah, H. Enrichment, spatial distribution of potential ecological and human health risk assessment via toxic metals in soil and surface water ingestion in the vicinity of Sewakht mines, district Chitral, Northern Pakistan. Ecotoxicol. Environ. Saf. 2018, 154, 127-136. [CrossRef] [PubMed]

17. Zhao, S.; Feng, C.; Yang, Y.; Niu, J.; Shen, Z. Risk assessment of sedimentary metals in the Yangtze Estuary: New evidence of the relationships between two typical index methods. J. Hazard. Mater. 2012, 241, 164-172. [CrossRef] [PubMed]

18. Duan, X.L. Exposure Factors Handbook of Chinese Population (Adults); China Environmental Science Press: Beijing, China, 2013.

19. Lu, X.; Zhang, X.; Li, L.Y.; Chen, H. Assessment of metals pollution and health risk in dust from nursery schools in Xi'an, China. Environ. Res. 2014, 128, 27-34. [CrossRef] [PubMed]

20. Li, L.Z.; Zhang, L.J.; Hu, G.C. The exposure and health risk assessment of the heavy metals in house dust from mineral areas, southwest of China. Asian J. Ecotoxicol. 2017, 12, 235-242.

21. De Miguel, E.; Izquierdo, M.; Gómez, A.; Mingot, J.; Barrio-Parra, F. Risk assessment from exposure to arsenic, antimony, and selenium in urban gardens (Madrid, Spain). Environ. Toxicol. Chem. 2017, 36, 544-550. [CrossRef]

22. Zhu, Y.; Zhao, S.; Li, R.; Meng, Q.; Zhang, Y.; Yan, L. Heavy metal contamination and bioavailability in shooting range soil. Acta Sci. Circum. 2011, 31, 148-156.

23. Zhu, Y.B.; Zhao, S.P.; Liu, X.D. Characteristics of heavy metals contamination and distribution in shooting range: A case study. Adv. Mater. Res. 2012, 414,132-138. [CrossRef]

24. Liu, Y.; Fang, Z.; Yang, Q.; Xie, C.; Wang, D.; Mao, H. Evaluation of heavy metal pollution in soils from a training ground based on GIS. Environ. Sci. 2012, 33, 319-324.

25. Liu, Y.; Fang, Z.; Yang, Q.; Xie, C.; Li, J. Analysis of the total concentration and the existing speciation of heavy metals in small arms shooting range soils. J. Saf. Environ. 2013, 13, 107-111.

26. Liu, Y.; Fang, Z.; Xie, C.; Li, J. Analysis of existing speciation and evaluation of heavy metals pollution of soil in a shooting range. Nat. Environ. Pollut. Technol. 2014, 13, 449-456.

27. Ministry of Ecology and Environment of the People's Republic of China. Soil Environmental Quality-Risk Control Standard for Soil Contamination of Agricultural Land (GB15618-2018); Ministry of Ecology and Environment of the People's Republic of China: Beijing, China, 2018.

28. Cao, X.; Ma, L.Q.; Chen, M.; Hardison, D.W., Jr.; Harris, W.G. Lead transformation and distribution in the soils of shooting ranges in Florida, USA. Sci. Total Environ. 2003, 307, 179-189. [CrossRef]

29. Stauffer, M.; Pignolet, A.; Alvarado, J.C. Persistent mercury contamination in shooting range soils: The legacy from former primers. Bull. Environ. Contam. Toxicol. 2017, 98, 14-21. [CrossRef]

30. Sehube, N.; Kelebemang, R.; Totolo, O.; Laetsang, M.; Kamwi, O.; Dinake, P. Lead pollution of shooting range soils. S. Afr. J. Chem. 2017, 70, 21-28. [CrossRef]

31. Perroy, R.L.; Belby, C.S.; Mertens, C.J. Mapping and modeling three dimensional lead contamination in the wetland sediments of a former trap-shooting range. Sci. Total Environ. 2014, 487, 72-81. [CrossRef] 
32. Bennett, J.R.; Kaufman, C.A.; Koch, I.; Sova, J.; Reimer, K.J. Ecological risk assessment of lead contamination at rifle and pistol ranges using techniques to account for site characteristics. Sci. Total Environ. 2007, 374, 91-101. [CrossRef]

33. Hoch, J.M.; Bruce, M. Metal contamination hotspots at unregulated firearm target shooting sites in the Everglades. J. Environ. Qual. 2019, 48, 755-761. [CrossRef]

34. Rantalainen, M.L.; Torkkeli, M.; Strömmer, R.; Setälä, H. Lead contamination of an old shooting range affecting the local ecosystem-A case study with a holistic approach. Sci. Total Environ. 2006, 369, 99-108. [CrossRef]

(C) 2020 by the authors. Licensee MDPI, Basel, Switzerland. This article is an open access article distributed under the terms and conditions of the Creative Commons Attribution (CC BY) license (http://creativecommons.org/licenses/by/4.0/). 